І.Б. Кіндрась', В.І. Дунаєвський², А.І. Ліптуга², В.І. Тимофєєв³, В.Й. Котовський ${ }^{3}$, С.С. Назарчук ${ }^{3}$ '1/нститут стоматології Національної медичної академії післядипломної освіти імені П.Л. Шупика, Київ ${ }^{2}$ Інститут фізики напівпровідників імені В.Є. Лашкарьова НАН України, Київ ${ }^{3}$ Національний технічний університет України «Київський політехнічний інститут імені Ігоря Сікорського», Київ

\title{
Інфрачервоне випромінювання з уражених ділянок та його реєстрація при щелепно-лицевій патології
}

Підвищення інформативності у встановленні діагнозу та динамічному спостереженні за процесом лікування пацієнтів із щелепно-лицевою патологією можна досягти шляхом застосування дистанційної інфрачервоної термографії в комплексі з іншими діагностичними методами. На основі термографічної діагностики розроблено методику обстеження пацієнтів із аурикуло-темпоральним синдромом, що позбавлена недоліків випробування харчовим подразником та проби Мінора. Впровадження сучасних методів обробки термограм і програмного забезпечення дозволяє підвищити рівень діагностичних можливостей та спростити роботу лікарятермографіста.

Ключові слова: термографія, щелепно-лицева патологія, градієнт, температура.

\section{Вступ}

Медична інфрачервона термографія - досить відомий метод обстеження пацієнтів за допомогою використання сучасних термографічних апаратів (Розенфельд Л.Г. и соавт., 1988; 2006; Diakides N.A., Bronzino J.D., 2006; Балашов А.А., Кацуба Д.С., 2014;

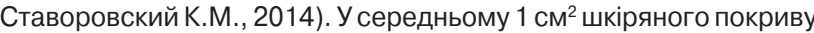
людини випромінює біля 40 Вт енергії. Відомо, що температура поверхні тіла залежить від трьох основних факторів: особливостей васкуляризації, рівня метаболічних процесів та відмінностей в теплопровідності (Крючок В.Г. и соавт., 2014). Порушення інфрачервоного випромінювання спостерігають у таких випадках:

- змінені структурні співвідношення судинної мережі вродженої аномалії, судинні пухлини

- зміни тонусу судин - порушення вегетативної іннервації, рефлекторні зміни тонусу;

- місцеві порушення кровообігу - травми, тромбоз, склероз судин;

- порушення венозного кровотоку - застій, зворотний тік крові внаслідок недостатності клапанів вен;

- локальні зміни теплопродукції - запальні вогнища, пухлини, деякі інші захворювання;

- зміни теплопровідності тканин - набряк, ущільнення тканин, зміни вмісту жирової тканини.

Такі порушення гемодинаміки, як венозний застій, погіршення артеріального притоку, патологічні зміни на рівні мікроциркуляторного русла, призводять до зміни температури тканин.

Сучасна інфрачервона термографія дозволяє виявляти анатомічну ділянку патологічних змін задовго до прояву клінічної симптоматики, визначати активність та характер процесів, що відбуваються в організмі людини.

Зазвичай розподіл температурних зон симетричних ділянок тіла є рівномірним. Єдиним методом, що дозволяє отримати найбільш достовірний розподіл температури та виявляти ділянки з аномальними значеннями температури, є дистанційна інфрачервона термографія (ДІТ).

Для правильної інтерпретації отриманої термографічної картини важливе також уміння лікаря узагальнити й інші результати діагностичних методів (ультразвукового та рентгенологічного).

У комплексному обстеженні хворих із запальними процесами щелепно-лицевої ділянки термографія безперечно надає цінну інформацію як в діагностичному, так і в прогностичному аспекті (Розенфельд Л.Г. и соавт., 2007; Тимофеев А.А. и соавт., 2009; Дурново Е.А. и соавт., 2012; Тимофеев А.А., 2012; Киндрась И.Б. и соавт., 2014; Кіндрась І.Б. та співавт., 2016).
Дослідження в динаміці післяопераційного періоду без шкоди здоров'ю хворого дозволяє своєчасно вносити корективи в консервативне лікування.

Цінність методу ДІТ полягає у визначенні не лише вогнища ураження, а й границь запального процесу. Деякі питання використання ДІТ при щелепно-лицевих захворюваннях розглянуто авторами робіт (Тимофеев А.А. и соавт., 2009; Дурново Е.А. и соавт., 2012; Тимофеев А.А., 2012; Киндрась И.Б. и соавт., 2014; Кіндрась І.Б. та співавт., 2016). Враховуючи важливість досліджень щодо застосування термографії в діагностуванні щелепно-лицевої патології, доцільно збільшувати обсяг робіт у цьому напрямку.

Мета - подальше дослідження інфрачервоного випромінювання з уражених ділянок та його реєстрація при щелепно-лицевій патології, що дозволить значно розширити діагностичну базу.

\section{Об'єкт і методи дослідження}

У роботі використовували вітчизняний термограф із матричним фотоприймачем (спектральна чутливість - 2-5,3 мкм, температурна чутливість $\left.-0,07^{\circ} \mathrm{C}\right)$.

Методика проведення термографічних обстежень докладно описана в роботі (Розенфельд Л.Г. и соавт., 2006).

\section{Результати та їх обговорення}

Нижче наведені термографічні зображення при щелепнолицевій патології.

\section{Термограма бешихового запалення}

Термограма пацієнта з діагнозом «бешихове запалення» представлена на рис. 1а. Спостерігається гіпертермія в ділянці шиї та правої половини нижньої щелепи з градієнтом температури $+1,7^{\circ} \mathrm{C}$. Для порівняння представлена термографічна візуалізація лівої ділянки обличчя та шиї хворого (рис. 1б). На рис. 1в показана термограма хворого з еритематозно-бульозною формою бешихового запалення обличчя. Градієнт температури в зоні гіпертермії становить $+2,9^{\circ} \mathrm{C}$

Термографічне зображення паротиту

Термограма пацієнта з лівобічним паротитом показана на рис. 2а. Для порівняння представлена термографічна візуалізація обличчя праворуч (рис. 2б). Температура вогнища ураження (виділено колом на рис. 22 ) має значення 39,$85 ; 38,65{ }^{\circ} \mathrm{C}$. Градієнт температури становить $+2,81 \ldots+4,04{ }^{\circ} \mathrm{C}$.

Термографічна візуалізація серозного лімфаденіту

Під час термографічного обстеження у пацієнта виявлена гіпертермія шийного відділу ліворуч із градієнтом температури 


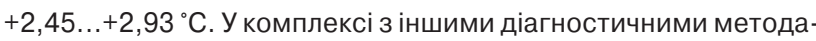
ми обстеження встановлено діагноз «гострий серозний лімфаденіт».

\section{Термограми хворого із запаленням}

занижньощелепних лімфатичних вузлів

Термограма пацієнта із двобічним запаленням занижньощелепних лімфатичних вузлів показана на рис. 4. Спостерігаються ділянки гіпертермії з градієнтом температури: праворуч $+3{ }^{\circ} \mathrm{C}$ ліворуч $+2,8^{\circ} \mathrm{C}$.

\section{Термографічне зображення калькульозного}

\section{субмаксиліту}

Лівобічний калькульозний субмаксиліт у стадії загострення показаний на рис. 5. Представлено термографічне зображення вогнищ ураження та загальної гіпертермії обличчя та шиї як наслідок запального процесу.

\section{Термографія стоматологічних захворювань}

На термограмі рис. 6а спостерігаємо гіпертермію в ділянці шиї та нижньої щелепи ліворуч внаслідок одонтогенного абсцесу щелепно-язичного жолобка від 3.8 нижнього зуба, ускладнений запальним інфільтратом лівої піднижньощелепної ділянки. Градієнт температури в ділянці запального процесу становить $+1,17^{\circ} \mathrm{C}$.

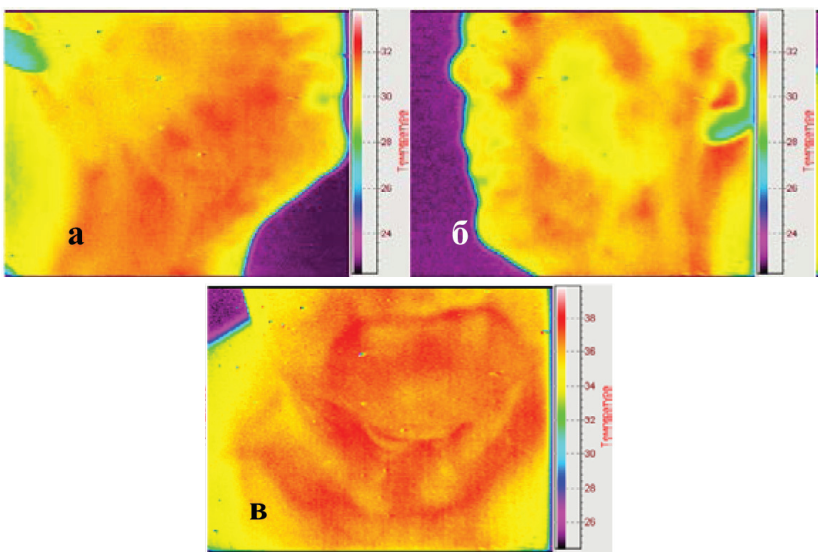

Рис. 1. Гіпертермія в ділянці шиї та правої половини нижньої щелепи (а). Ліва частина обличчя показана для порівняння (б). Бешихове запалення, еритематозно-бульозна форма (B)
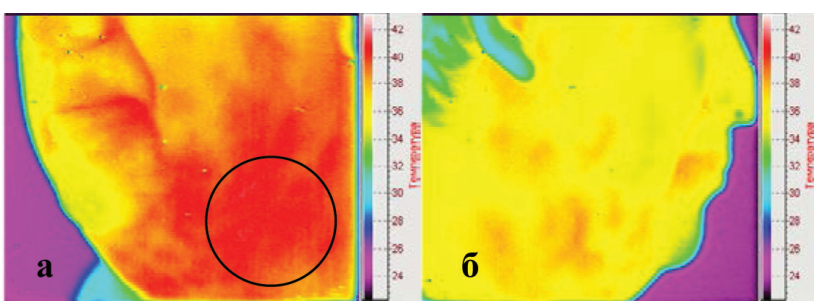

Рис. 2. Лівобічний паротит

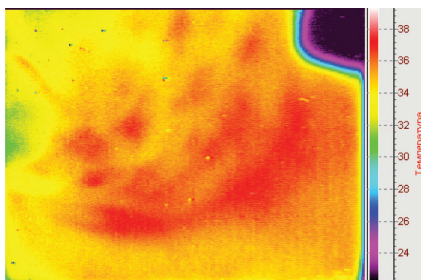

Рис. 3. Гострий серозний лімфаденіт
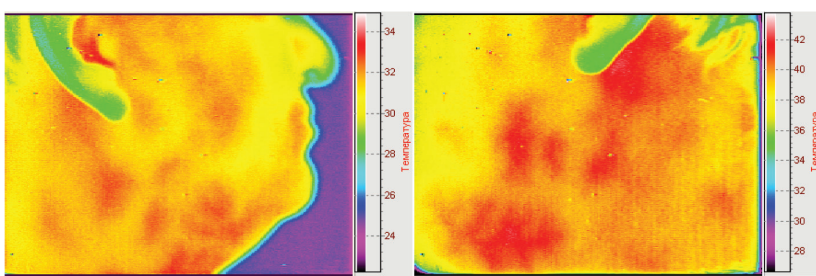

Рис. 4. Двобічне запалення занижньощелепних лімфатичних вузлів
Подібна картина спостерігається у хворого на рис. 6б, діагноз «Одонтогенний абсцес щелепно-язичного жолобка від 3.7 нижнього зуба ліворуч, ускладнений періадентитом». Градієнт температури становить $+2,5^{\circ} \mathrm{C}$.

Термографічна візуалізація абсцесу піднижньощелепної ділянки праворуч від 4.7 зуба (післяопераційний стан) представлена на рис. 7. Градієнти температури: $\Delta \mathrm{T}_{2-1}=+1,27^{\circ} \mathrm{C} ; \Delta \mathrm{T}_{3-1}=-3,56{ }^{\circ} \mathrm{C}$; $\Delta \mathrm{T}_{4-1}=-1,18^{\circ} \mathrm{C} ; \Delta \mathrm{T}_{5-1}=+1,38^{\circ} \mathrm{C}$.

Термографія хворого з плеоморфною аденомою привушної залози

Термографічна візуалізація стану після операції з приводу плеоморфної аденоми привушної залози показана на рис. 8 . У результаті комплексної термографічної діагностики виявлено гіпертермію черевної ділянки в зоні проекції печінки та шлунку (рис. 8в, г) як наслідок прийому лікарських засобів, що призвело до функціональних розладів шлунково-кишкового тракту.

На основі термографічної діагностики розроблена методика обстеження хворих з аурикуло-темпоральним синдромом, що позбавлена недоліків випробування харчовим подразником та проби Мінора. У початковому стані з боку ураження спостерігається вогнище гіпертермії, частіше у проекції занижньощелепної ями, кута та гілки нижньої щелепи, гомогенної структури

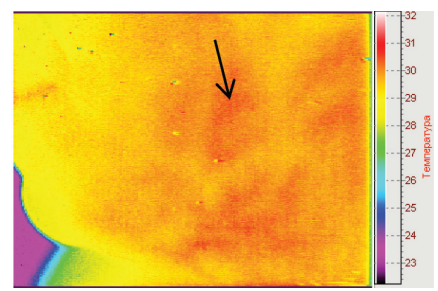

Рис. 5. Лівобічний калькульозний субмаксиліт

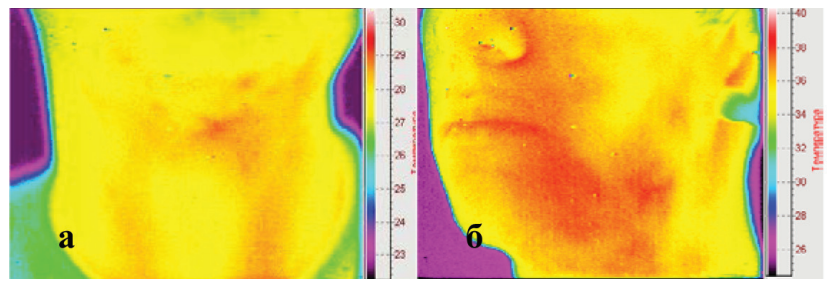

Рис. 6. Одонтогенний абсцес щелепно-язичного жолобка (а). Одонтогенний абсцес щелепно-язичного жолобка, ускладнений періадентитом (б)

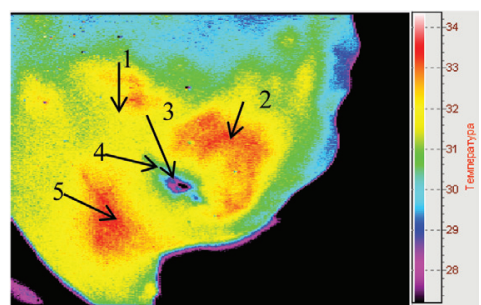

Рис. 7. Абсцес піднижньощелепної ділянки від 4.7 зуба праворуч. Післяопераційний період

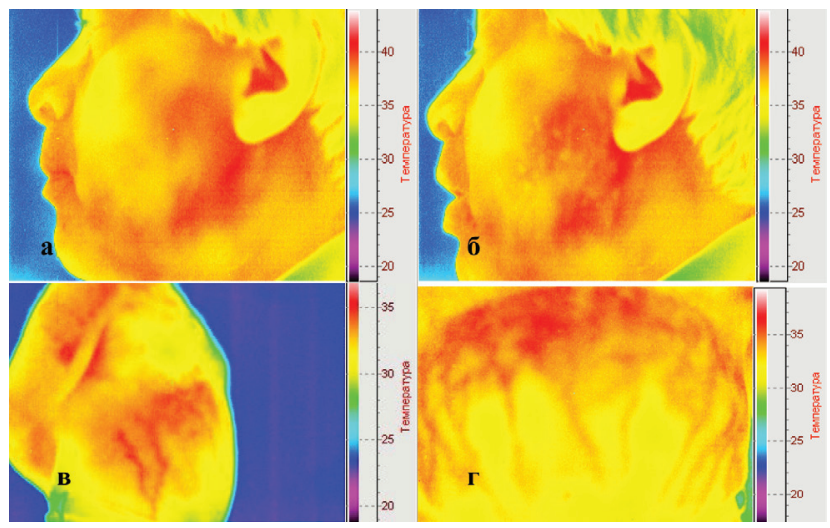

Рис. 8. Аурикуло-темпоральний синдром (a, б). Гіпертермічні зони черевної ділянки $(B, \Gamma)$ 
Таблиця. Результати досліджень

\begin{tabular}{|c|c|c|c|}
\hline Діагноз & Термографічна візуалізація & Градієнт температури & Примітки \\
\hline Бешихове запалення & Гіпертермія в ділянці ураження & $+1,7 \ldots+2,9^{\circ} \mathrm{C}$ & Термографічна картина неоднорідна \\
\hline Лівобічний паротит & Гіпертермія вогнища ураження & $+2,81 \ldots+4,04^{\circ} \mathrm{C}$ & \\
\hline Гострий серозний лімфаденіт & Гіпертермія шиї та прилеглих ділянок & $+2,45 \ldots+2,93^{\circ} \mathrm{C}$ & $\begin{array}{l}\text { Термоасиметрія зон ураження } \\
\text { та прилеглих ділянок }\end{array}$ \\
\hline $\begin{array}{l}\text { Двобічне запалення защелепних } \\
\text { лімфатичних вузлів }\end{array}$ & $\begin{array}{l}\text { Гіпертермія нижньої щелепи та защелепної } \\
\text { ділянки }\end{array}$ & Праворуч $+3{ }^{\circ} \mathrm{C}$, ліворуч $+2,8^{\circ} \mathrm{C}$ & $\begin{array}{l}\text { Чіткі границі ділянки ураження зі знижен- } \\
\text { ням температури від центру ураження }\end{array}$ \\
\hline Лівобічний калькульозний субмаксиліт & Гіпертермія вогнищ ураження, обличчя та шиї & & Термографічна картина неоднорідна \\
\hline $\begin{array}{l}\text { Ускладнений одонтогенний абсцес } \\
\text { щелепно-язичного жолобка }\end{array}$ & Локальна гіпертермія в ділянці ураження & В ділянці ураження $+1,17 \ldots+2,5^{\circ} \mathrm{C}$ & Локальна гіпертермія \\
\hline $\begin{array}{l}\text { Абсцес піднижньощелепної ділянки } \\
\text { від } 4.7 \text { зуба. Післяопераційний стан }\end{array}$ & $\begin{array}{l}\text { Гіпотермія ділянки абсцесу та гіпертермія } \\
\text { оточуючих тканин }\end{array}$ & $\begin{array}{l}\text { В ділянці абсцесу }-1,18 \ldots-3,56{ }^{\circ} \mathrm{C} \text {; } \\
\text { прилеглі тканини }-+1,27 \ldots+1,38^{\circ} \mathrm{C}\end{array}$ & \\
\hline $\begin{array}{l}\text { Плеоморфна аденома привушної залози, } \\
\text { післяопераційний стан }\end{array}$ & $\begin{array}{l}\text { Вогнище гіпертемії занижньощелепної ями, } \\
\text { гомогенна структура з нечіткими контурами }\end{array}$ & $+1,5 \ldots+2,0^{\circ} \mathrm{C}$ & $\begin{array}{l}\text { Гіпертермія печінки та шлунково-кишко- } \\
\text { вого тракту }\end{array}$ \\
\hline
\end{tabular}

з нечіткими контурами. Градієнт температури між зонами ураження та зоною здорового боку становить $+1,5 \ldots-2,0$ ㄷ․ Після проби 3 харчовим подразником (яблуко, лимон) (рис. 8б) відзначали різке збільшення зони гіпертермії, яка поширювалася на привушножувальну, щічну, а іноді й вилицеву ділянку. При цьому спостерігали збільшення градієнта температури на 0,5-1,0 으, що дозволяє здійснити ранню діагностику аурикуло-темпорального синдрому і проводити спостереження за динамікою розвитку захворювання та ефективністю лікування

Викладені результати досліджень зведені в таблицю.

\section{Висновки}

Отримані термографічні зображення при щелепно-лицевій патології: бешиховому запаленні, лівобічному паротиті, гострому серозному лімфаденіті, двобічному запаленні защелепних лімфатичних вузлів, лівобічному калькульозному субмаксиліті, ускладненому одонтогенному абсцесі щелепно-язичного жолобка, абсцесі піднижньощелепної ділянки від 4.7 зуба (післяопераційний стан), плеоморфній аденомі привушної залози (післяопераційний стан).

Ділянки ураження характеризуються гіпертермією з градієнтами температур $+1,17 \ldots+4,04{ }^{\circ} \mathrm{C}$. Величина градієнта температури залежить від характеру запального процесу, вираженість якого поступово знижується під час лікування. Термографічна картина показує не лише вогнище запального процесу, а й стан оточуючих тканин, та надає можливість у динамічному спостереженні оцінювати ефективність лікувальних заходів. Водночас за допомогою ДІТ можна виявляти побічні негативні ускладнення, пов'язані зі впливом лікарських засобів, що застосовують під час лікування.

Впровадження термографічної діагностики розширює діагностичну базу виявлення щелепно-лицевих захворювань. Комплексне застосування рентгенологічного, ультразвукового і термографічного досліджень дозволяє своєчасно встановити діагноз та вибрати найоптимальніший метод лікування і спостерігати в динаміці його ефективність.

\section{Список використаної літератури}

Балашов А.А., Кацуба Д.С. (2014) Способ определения рабочих участков экспериментальных термограмм. Вопросы современной науки и практики. Ун-т им. В.И. Вернадского, 3(53): 214-219.

Дурново Е.А., Марочкина М.С., Хомутинникова Н.Е. и др. (2012) Возможности инфракрасной термографии в комплексной диагностике заболеваний челюстно-лицевой области (https://www.science-education.ru/ru/article/ view?id=6657).

Киндрась И.Б., Дунаевский В.И., Назарчук С.С., Кузнецова Н.И. (2014) Дистанционная инфракрасная термодиагностика при заболеваниях околоушной железы. Зб. наук. праць Ін-ту стоматол. НМАПО імені П.Л. Шупика, 5: $165-167$.

Кіндрась І.Б., Дунаєвський В.І., Назарчук С.С. та ін. (2016) Терм0графія щелепно-лицевих захворювань. Зб. наук. праць Ін-ту стоматол. НМАПО імені П.Л. Шупика, 6: 181-185.

Крючок В.Г., Лещенко В.Г., Малькевич Л.А. и др. (2014) Диагностические возможности термографии в оценке эффективности комплексного лечения дегенеративно-дистрофических заболеваний суставов и позвоночника с включением современных сочетанных методов физиотерапии. Мат. республ. науч.-практ. конф., С. 37-44.

Розенфельд Л.Г., Венгер Е.Ф., Коллюх А.Г. и др. (2007) Матричный полупроводниковый фотоприемник инфракрасного излучения и его применение в биотехнологиях. Электроника и связь. Биомед. приб. сист., 2: 27-29.
Розенфельд Л.Г., Венгер Е.Ф., Лобода Т.В. та ін. (2006) Дистанційний інфрачервоний термограф з матричним фотоприймачем та досвід його використання у клінічній лікарні. Укр. радіолог. журн., 5: 451-456.

Розенфельд Л.Г., Терновой Н.К., Сулименко Ю.Н. и др. (1988) Основы клинической дистанционной термодиагностики. Здоров'я, 222 с.

Ставоровский К.М. (2014) Автоматическая диагностика и анализ термограмм в медицинской практике. Electronics and communications, 19(1): 47-55.

Тимофеев А.А. (2012) Руководство по челюстно-лицевой хирургии и хирургической стоматологии. Киев, 1046 с.

Тимофеев А.А., Киндрась И.Б., Венгер Е.Ф. и др. (2009) Дистанционная инфракрасная термодиагностика при заболеваниях челюстно-лицевой области. Электроника и связь, 2: 236-240.

Diakides N.A., Bronzino J.D. (2006) Medical Infrared imaging. CRC Press Taylor Group LLC. London, New York, 451 p.

\section{Инфракрасное излучение с пораженных участков и его регистрация} при челюстно-лицевых патологиях

\section{И.Б. Киндрась, В.И. Дунаевский, А.И. Липтуга, В.И. Тимофеев, В.И. Котовский, С.С. Назарчук}

Резюме. Повышения информативности в установлении диагноза и динамическом наблюдении за процессом лечения пациентов с челюстно-лицевой патологией можно достичь путем применения дистанционной инфракрасной термографии в комплексе с другими диагностическими методами. На основе термографической диагностики разработана методика обследования больных с аурикулотемпоральным синдромом, лишенная недостатков испытания пищевым раздражителем и пробой Минора. Внедрение современных методов обработки термограмм и программного обеспечения позволяет повысить уровень диагностических возможностей и упростить работу врача-термографиста.

Ключевые слова: термография, челюстно-лицевая патология, градиент, температура.

\section{Infrared light from affected areas and its registracion in maxillofacial pathologies \\ I.B. Kindras, V.I. Dunaevskiy, A.I. Liptuga, V.I. Tymofeev, V.I. Kotovskyi, S.S. Nazarchuk}

Summary. Increasing information in diagnosis and dynamic monitoring of the treatment of patients with maxillofacial pathologies can be achieved by using remote infrared thermography in combination with other diagnostic methods. The survey procedure of patients with auricolotemporal syndrome, which is devoid of the disadvantages of food irritation and Minor tests, was developed based on the thermographic diagnostics the technique of examination. The introduction of modern methods of processing thermograms and software allows to increase the level of diagnostic capabilities and to simplify the work of the doctor - thermographer.

Key words: thermography, maxillofacial pathology, gradient, temperature.

\section{Адреса для листування:}

Кіндрась Ігор Борисович

01103, Київ, вул. проф. Підвисоцького, 4 А

НМАПО імені П.Л. Шупика,

кафедра щелепно-лицевої хірургії

E-mail: igorkindras@nmapo.edu.ua 